\title{
COVID-19 impacts on beaches and coastal water pollution: Management proposals post-pandemic
}

Ormaza-González, Franklin I. 1) and Divar Castro-Rodas 2)

1. Faculty of Maritime Engineering and Marine Sciences, FIMCM. ESPOL Polytechnic University, Escuela Superior Politécnica del Litoral, ESPOL, Ecuador

2. Centro Nacional de Acuicultura e Investigaciones Marinas, CENAIM. Escuela Superior Politécnica del Litoral, ESPOL. Campus Gustavo Galindo Km. 30.5 Vía Perimetral, Guayaquil, Ecuador. P.O. Box 09-01-5863

\begin{abstract}
The COVID-19 pandemic has obliged Governments all around the world to take confinement and social distancing measures. The reduction of leisure and production activities on beaches and ports have disappeared direct and indirect contamination such as plastics, hydrocarbon spill, microbiological loads, noise level, etc. leading to temporary improved environmental conditions, converting the beaches similar to Marine Protected Areas. Some conditions are briefly analyzed through local surveys and in situ observations in the popular beaches and ports of Salinas, Manta and Galápagos. 97-99 \% of surveyed people agreed that beaches have notoriously improved during confinement at least from visual observation. On a scale from 1 (worst) to 5 (best), the beaches were rated 2.23 and 2.83 (less than acceptable) before quarantine, and 4.48 and 4.33 after it for Salinas and Manta respectively. The beaches have less garbage in general and plastic, even though there has been an increase in plastic and face mask production around the world. In Salinas, $72 \%$, and $23 \%$ of surveyed people have seen small pelagic fish, whilst in Manta $75 \%$, and $41 \%$ of people saw the same, but also $17 \%$ of people have seen whales (humpback and shark-whales) and dolphins practically swimming on the beach. Manta rays, turtles, and other types of species were also observed. In Galapagos beaches, turtles have been observed many more times than usual. The main plausible reason is the decrease in noise level. It is recommended to take this unique opportunity, to construct a baseline data and information on physical, chemical, biological, microbiological coastal oceanographic science, and from them to establish a proper Coastal Zone Management based on beach description, water, and beach quality, human dimension, and economic value indexes. This data and information construction should ideally be done before the beaches are open.
\end{abstract}

Keywords. COVID-19, confinement, beaches, pollution, tourism

Covid-19 impacts on beaches and coastal water pollution: Management proposals post pandemic. Ormaza-González, Franklin I., Divar Castro-Rodas 


\section{Introduction.}

"As the COVID-19 pandemic sweeps through the world, we must reassess the principles that guide our individual and collective responses and the way we operate in society. In the face of crisis, we must lead with science and humanity", the Editor-a (2020) recently asserted.

At the moment of submitting () this communication, the COVID-19 pandemic is having (probably underestimate) 5344521 confirmed cases and 342695 deaths according to the John Hopkins university Corona Resource Center (24/may/2020), is the US the country with most of the cases (1 626 258) and deaths (97 149), at the same time for Ecuador the figures are 36258 and 3096 respectively. The outbreak may go long and so far unforeseeable time, thus the lockdowns and social distance measures applied practically all around the globe will continue. An early work by Bloom et al., (2018) warms the impacts of pandemic over economies can be sizable over the short and long term. Individual and social tragedies go beyond imagination, with nightmarish economy impacts with a possible sales drop of 50-75 $\%$ (De Vito and Gomez, 2020) in relation to pre-COVID conditions. With: 1) air, water and road transportation very limited or completely prohibited in some places; 2 ) parks, beaches, museums, etc. as well as social activities closed, 3) very low consumer demands for products and services, the economy has dramatically been hit, and in some places almost disappeared. One of the most affected activities is tourism; according to UNWTO (2020) the decline since the arrival COVID-19 is around 52-78\%; just in Q1 2020 the losses were around 80 billion US\$, for the whole year, it would be 100 to 120 billion US\$ direct losses. In Ecuador touristic activities losses could amount 540 million US\$ in three months halt (Statista, 2020); marine and coastal tourism will be one of the most affected activities. The beach towns of Salinas, Manta, and Galapagos in Ecuador would perhaps be the most impacted.

It is accepted that tourism exerts strong pressure on natural sources and directly or indirectly contribute to pollution (Navarro 2019) and excessive demand on coastal benthonic and pelagic fisheries (BudzichTabor et al., 2014). At the same time plastic or any type of debris, and the microbiological load is a relevant impact due to beach tourism (NRDC, 2014). Mechanical waves (wavelength, frequency, period and decibels) travel much faster and longer distance through water than in the air; probably the noise produced by beachgoers activities like partying (high decibels level music), yelling, shouting, etc. could be suspected to cause aggressiveness and scare of marine fauna (see, Stocker, 2002). Pervasive anthropogenic as just recreational the activity could severely affect turtle behavior and ecology (Samuel et al., 2005) and send coastal pelagic fish away. Even worst, noise pollution from on board engines of transport, fishing and leisure boats have been shown to disturb all fish species, being this notorious for marine mammals, sea, birds, turtles, etc. (Hazel et al., 2007; Ketten, 2008).

Salinas-Santa Elena is one the most visited beaches south Ecuador, around 400 thousand tourists arrive at the Province between January and June, 200 thousand of these come to Salinas, where its local population is just around 70 thousand people (GAD-Salinas, 2020). Galápagos islands have a local population of around 30 thousand people, but during 2019, 271 thousand tourists arrived at their protected areas (PNG, 2020), thus exerting high pressure on marine resources and contamination (Pecot and Ricuarte-Quijano, 2019). Mestanza et al. (2019a) have found that the beaches of Galápagos are one of the cleanest of Ecuador, whilst Salinas is the most affected in terms of plastic litter. Nonetheless, microplastics have been found in Galapagos recently (Santander, 2016) and there are reports of inefficient planning and management of marine environment (Walsh and Mena, 2013; Mestanza et al., 2019a).

Covid-19 impacts on beaches and coastal water pollution: Management proposals post pandemic. Ormaza-González, Franklin I., Divar Castro-Rodas 
Another important fact, is that reliance on bottled water has increased exponentially since the outburst of COVID-19 and will keep growing, especially in those places where there is high touristic activity and inflow of foreign population like in Galapagos, Salinas or Manta (Ecuador). The Galápagos islands suffer from having good quality potable water, reports suggest the presence of Escherichia coli in 2-30\% (Grube et al., 2020). Masks and gloves are now being used by most if not all people due to COVID-19 pandemic, in Ecuador and many other countries their use is obligatory. This new sort of garbage is going beyond sanitary disposal management, which is poor and inappropriate (Calma, 2020). Therefore, there is a new contamination menace to coastal waters and beaches apart from increase the volume of empty bottles (Hyde, 2020).

The COVID-19 pandemic confinement and social distancing are producing some positives impacts (at least temporarily) on the environment such as less atmospheric gases $\left(\mathrm{CO}_{2}, \mathrm{SO}_{2}, \mathrm{NO}_{2}\right.$, etc.); Rosenbloom and Markard (2020) recently asserted that air pollution and emission of greenhouse gases are decreasing notably, Le Quéré et al., (2020) have reported $17 \%$ less of typical daily emission of $\mathrm{CO}_{2}$ (and other gases). Other intrusive pollution types (noise, wastes, etc.) in the atmosphere, biosphere, and hydrosphere, etc. have also decreased significantly in some populated areas due to reduced transportation, electricity, industrial production (Rosenbloom and Markard, 2020), leisure and fishing activities.

The contamination on the beaches and coastal water has been petering out with the quarantine measures taken by all countries in order to fight the spread of COVID-19. Beaches from Acapulco (Mexico), Barcelona (Spain) and Salinas (Ecuador) now have much transparent and cleaner waters (Zambrano-Monserrate et al. 2020); the Vembanad lake has around 16\% less suspended solids than before the pandemic (Yunus et al., 2020). Anecdotal reports in social media make the point about the presence of marine mammals close to beaches, perhaps to the considerable reduction of the noise level. In general, environmental conditions will be better (at least temporarily) in terms of lower pollution levels (chemical, physical, biological, microbiological, etc. (Yunus et al., 2020). Therefore, all beaches, have become a sort of temporary Marine Protected Areas.

There has been a temporal environmental improvement, but perceptions of people who are suffering day by day in places where the economy depends on tourism or fishing activities, need to be measured properly in order to have a scientific baseline of data and information in order to articulate a proper tourism and coastal pollution management post COVID-19 pandemic. This work seeks to understand some people information and priorities based on environmental qualitative information of three main sets of beaches of Salinas, Manta, and Galápagos. We think it is a unique opportunity all around the world to create a scientific baseline, as beaches have become temporally a sort of Protected Marine Areas, in order to initiate comprehensive management programs (Partelow et al., 2015) for the near future. Recommendations are proposed too.

Covid-19 impacts on beaches and coastal water pollution: Management proposals post pandemic. Ormaza-González, Franklin I., Divar Castro-Rodas 


\section{Materials/Method}

Salinas, Manta, and two ports of Galapagos were chosen for local interviews and observations. Salinas (around $2^{\circ} 12^{\prime} \mathrm{S}, 80^{\circ} 56^{\prime} \mathrm{W}$ ) is the most popular and visited beach of Ecuador; its economy depends almost completely on tourism, the beaches are diverse from cliffs to fine sand beaches and areas where to swim is relatively safe. Manta (around $0^{\circ} 57^{\prime} \mathrm{S}, 80^{\circ} 42^{\prime} \mathrm{W}$ ) is the second most important port for luxury, fish and merchant ships, it also has wide and long beaches; Manta represents the fourth main economy of Ecuador. Galapagos Islands (Pto Ayora $0^{\circ} 45^{\prime} \mathrm{S}, 90^{\circ} 18 \mathrm{~W}$ and Baquerizo Moreno $0^{\circ} 54^{\prime} \mathrm{S}, 89^{\circ} 36^{\prime} \mathrm{W}$ ) are the main port of Galapagos, whose principal and the only economy is foreign tourism. The islands of Galapagos are a protected Marine Reserve with $133 \mathrm{~km}^{2}$, the biggest and most important in the world (Caryl-Sue et al., 2011, Barragán and Chuenpagdee, 2015) and the first World Heritage Sites named by the UNESCO (Walsh and Mena, 2013) due to its inimitable ecosystem.

The data obtained is from the visual perception of beaches and fish species watching. Surveys (15 may 2020) were carried out for at least 76 hours via Google (https://www.google.com/intl/en-

GB/forms/about/, see supplemental data) as it was impossible to visit the beaches and carry on surveys face to face due to COVID-19 social restrictions. The people interviewed were those living in the named cities and in front of the sea o close to it. The survey was based on knowledge, living experience, observation, and willingness of doing things better for local tourism and conservation of species. An observer in a quarantined boat in Galapagos reported turtles from 15 March to 30th April.

\section{Results}

Manta and Salinas had a quick response, $>90 \%$ of responses were within 24 hours; except Galapagos where internet connection sometimes is poor (Walsh and Mena, 2013). In Salinas 69 and Manta 39 people responded to the survey. To the question if the beach and water have visually changed? The answer was yes $99 \%$ and $86 \%$ respectively, and 1 and $14 \%$ said "No" in the same order because the beaches were free of people over a period of three months approximately they said. In Salinas $45 \%$ assured that beaches and water are now clean; $28 \%$ with less plastic and $27 \%$ the water was more transparent (Fig. 1). Whilst in Manta the answers were 44, 36, and $20 \%$ in the same order. In both places, $97 \%$ of surveyed people believe that there has not been noise pollution during confinement time, which is beneficial to the marine ecosystem, as well as to residents.

Surveyed people mostly ( $88 \%$ and $92 \%$ respectively) have seen increased marine activity during the quarantine period, this is linked to the low interaction of humans and there is no noise on the beach or at sea (by boat engines), therefore marine life has come back.

In Salinas, $72 \%$ and $23 \%$ (Fig. 1) of surveyed people have seen Fish (sardines, mackerel, etc.,) and dolphins respectively practically on the beach. Whilst in Manta $75 \%$ and $41 \%$ of people saw the same, but also $17 \%$ of people saw whales (humpback and shark-whales), turtles, manta rays, and other types of species were also reported. These marine species generally do not get close to the coast. Many videos on the web social media have shown as ever shark-whales and orcas along the Ecuadorian coast (Zambrano-Alvarado, 2020).

They rated Salinas beach before and after 10 weeks of quarantine, as 2.23 and 4.48 respectively on a scale from 1 (worst) to 5 (best), that would be a sort of intermediate and as ever good categorization. In Manta

Covid-19 impacts on beaches and coastal water pollution: Management proposals post pandemic. Ormaza-González, Franklin I., Divar Castro-Rodas 
the categorization was similar, 2.83 before and 4.33 after. Interviewed people deem overall that the beaches have improved their quality in every sense.

Salinas and Manta residents were afraid that if beaches were suddenly open, chemical, plastic, garbage and noise contamination and the new pandemic outbreak will occur. At the same time, 93\% and 92\% respectively of surveyed people agree that tourism should be reactivated neatly, to revive the local economy while avoiding a new pandemic outbreak.

Fig. 1. Opinion from Salinas and Manta. superior and bottom panel Salinas and Manta respectively. The " $y$ " ax is the number of people.

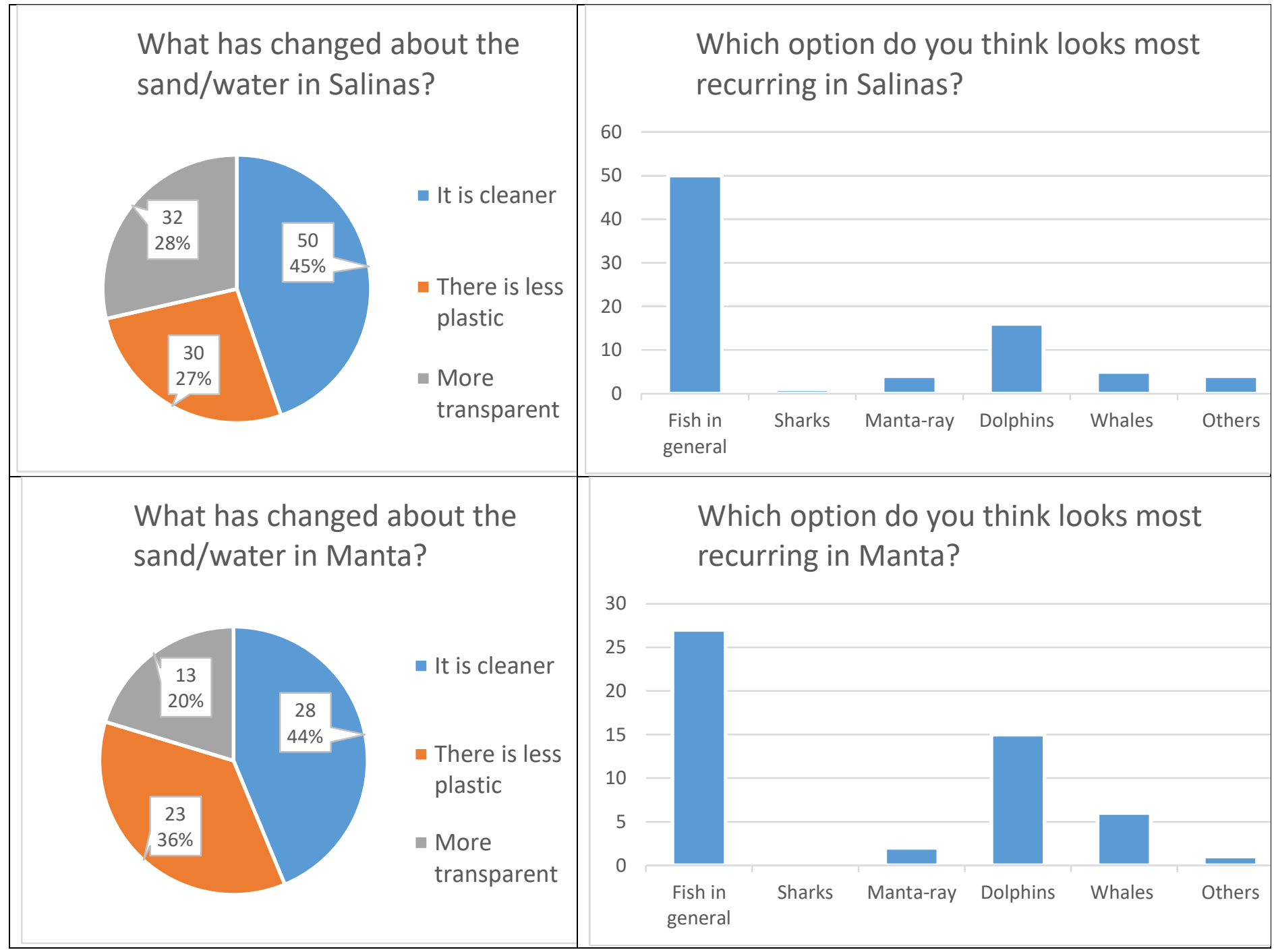

The question about if they knew of the existence of wastewater treatment plants, $77 \%$ are unaware of it. Finally, most of the people surveyed in Salinas were a general citizen (54\%), followed by $22 \%$ as academicians, and the rest researchers and people involved with tourism, but in Manta $89 \%$ regarded themselves, common citizen, $8 \%$ and $3 \%$ were involved with tourism and academy respectively.

Covid-19 impacts on beaches and coastal water pollution: Management proposals post pandemic. Ormaza-González, Franklin I., Divar Castro-Rodas 


\section{Discussion}

The COVID-19 pandemic has put everybody under emotional, economic, health, etc. distress, therefore to conduct face to face or online surveys under these circumstances could be difficult (Labott et al., 2013). Thus very few and quite simple questions were made. The surveys from Salinas and Manta were mostly responded within 24 hours, but from Galápagos, there were less than 5 replies, however, there was anecdotic information similar to those obtained in Salinas and Manta.

There is almost a unanimous opinion that beaches (sand and coastal water) have notoriously improved during confinement at least from the visual point of view. In the scale from 1 (worst) to 5 (best), the beaches were rated 2.23 and 2.83 (less than acceptable) before quarantine and 4.48 and 4.33 after it for Salinas and Manta respectively. The beaches have less garbage in general and plastic, even though there has been an increase in plastic and face mask production around the world (Calma, 2020; Eljarrat, 2020). There is a direct relationship between fish demand and tourism (Budzich-Tabor et al., 2014), as tourism activities stopped, the fishery markets of both cities were partially closed, so there is less artisanal fishing impact. Different types of species in the three places such as small pelagic fish and marine mammals as dolphins, orcs, whales, sharks, sea lions, and turtles have been observed by the surveyed people, also social network (Zambrano-Alvarado et. al. 2020). A marine biologist from Galapagos reported watching turtles close to the bay (I. San Cristobal) between 10 to 15 times a day; before the confinement, turtles were seen rarely in that area. The plausible reason for this is the decrease of noise, it has been shown how it affects the behavior of dolphins, sea turtles, sea birds, and other species (Samuel et al., 2005; Hazel et al., 2007; Ketten, 2008).

Similarly, it has been reported by news (Zambrano-Alvarado, 2020), papers (Zambrano-Monserrate, 2020) social networks, and public videos (please supplemental material videos) that coastal water is more transparent and bluish-turquoise color, and looks with less suspended particulate matter or phytoplankton. Along the coastal line and west to Galapagos $\left(92^{\circ} \mathrm{W}\right)$, there are two currents that provide nutrients, cooler and saltier water: The Cromwell and Humboldt. The Cromwell (Knaus, 1963) is a sub superficial currents that upwell west Galapagos, even gets east (Pak and Zaneveld, 1973) around $84 \mathrm{~W}$ and closer to the coastal line of Ecuador. The Humboldt (Montecino and Lange, 2009) is a coastal current from the Antarctic that reaches Chilean, Peruvian, and Ecuadorian coasts (May-December). Additionally, the north equatorial current (0.2-1.3 m/s, https://www.windy.com/-Currentscurrents?currents,-2.076,-86.506,6,i:temp, m:dGUadDS) during Jan-April flows into Ecuadorian coasts and north Galapagos. Only the Cromwell and Humboldt provide a flow of 39 and 12 Sverdrup, that can renew coastal surface waters $(100 \mathrm{~m})$. Thus it is reasonably considered, that coastal waters have been renewed a few times too transforming them into a sort of pristine water. This is perceived by the people according to the survey.

Most people responded that they did not know if there were wastewater plants. Ecuador a deficit of wastewater treatment plants, only $29.3 \%$ (INEC 2016) of sewage water has some type of primary treatment before they are discharged in natural water bodies, although there is legislation that prohibits discharge wastewater without treatment (Acuerdo № 97/A). Salinas sewage work only serves to $30 \%$ of the local population (Castro 2017), but not all the sewage is treated, only a small part of it is primarily treated and the rest is discharged to the seaside or badly constructed latrines which permeates eventually to the seaside, leading to incipient eutrophication, high microbiological load and other impacts. Walsh and Mena (2013) also report contamination from domestic non-treated in Galapagos. The absence of tourism has almost disappeared the pressure on the overloaded water treatment in

Covid-19 impacts on beaches and coastal water pollution: Management proposals post pandemic. Ormaza-González, Franklin I., Divar Castro-Rodas 
Salinas, Manta, and Galapagos, therefore eutrophication, grease, fecal contamination, etc. have dramatically decreased; Castro (2017), found a direct relation of phytoplankton growth and dissolved P as a product of residual untreated waters. However, most surveyed people are not aware if there are wastewater treatment plants and probably they are not aware of the problems associated with the untreated sewage water. This fact has produced a reduction in wastewater pollution, thus the water has become cleaner, apart from that full renovation of the coastal waters due to oceanic currents.

\section{Conclusions}

All three sites analyzed are under an aggressive and generally poorly organized tourism-driven economy as Stumpf et al., (2013) warned, which have produced littered beaches and polluted waters. The population residing in Salinas and Manta has clearly noticed a positive change in the beaches due to the absence of tourists due to the outbreak of COVID-19. The arrival of marine species, reduction in levels of noise and environmental pollution have been the highlights of the survey, and they corroborate the general perception found in the social media. The positive and temporal environmental impacts of the COVID-19 pandemic would ideally oblige to a neat and organized return of tourism, production, and fishing activities. There is a matchless opportunity to make these activities sustainable in time in spite of economic constraints that could cause at the beginning. As never ever, most of the coastline has become a sort of marine protected areas; this unparalleled opportunity to construct a baseline knowledge from almost pristine beaches and coastal waters. This baseline in turn will help to carry out real sustainable tourism and coastal fisheries by ICZM processes (Mestanza et al. 2019b). Also water and beach quality indexes described by Lucrezi et al. (2016) should be implanted. As Pearson et al. (2020) have suggested COVID-10 with its social, economic, health and economic consequences is the opportunity to reshape near, medium, and long time scale of management, especially environment like the beaches and its marine resources.

\section{Recommendations}

COVID-19 pandemic is causing enormous and unpredictable changes in society that will affect our lives for generations to come (Editor-b, 2020), how it interacts with society will be a new thing. The general recommendations to decision-makers and managers are to obtain that baseline of data and information before full reactivation of the industrial, tourism, fishing etc., activities. The baseline at least must account for biodiversity microbiological, chemical characterization of water bodies and sand without forgetting the description and human dimension.

Conflict of interest. There is not any conflict of interest

Work responsibilities. FIOG designed the idea of the research and survey, wrote the whole paper. DCR carried out the survey, work out the results of the survey, and organized them. Design the graphical abstract.

Covid-19 impacts on beaches and coastal water pollution: Management proposals post pandemic. Ormaza-González, Franklin I., Divar Castro-Rodas 
Acknowledgments. To Daphne my wife, who has been very closed to the paper construction, her valuable conversations during this quarantine have been useful. Marine biologist Xavier Romero observations in Galápagos are greatly appreciated

\section{References}

Acuerdo № 97/A - Norma de calidad ambiental y de descarga de efluentes al recurso agua (Anexo 1, Libro VI de la Calidad Ambiental, del Texto Unificado de la Legislación Secundaria del Ministerio del Ambiente). Last Access 23/May/2020. https://www.informea.org/es/node/333086.

Barragán Paladines, M.J., R. Chuenpagdee. 2015. Governability assessment of the Galapagos Marine Reserve. Maritime Studies 14, 13. https://doi.org/10.1186/s40152-015-0031-z

Bloom, D.E., D. Cadarette, J.P. Sevilla 2018. Epidemics and economics. Finance Develop., 55, pp. 46-49. Budzich-Tabor U., M. Burch, S. Gomes da Silva. 2014. "Linking fisheries to the tourism economy". ISBN 978-92-79-40593-8. DOI 10.2771/7410.

Calma J. 2020. The-covid-19-pandemic-is-generating-tons-of-medical-waste. https://www.theverge.com/2020/3/26/21194647/. Accessed date: 5 May 2020.

Caryl-Sue M., Mary Crooks, C. Johnson. 2011. Case Study: Galápagos Marine Reserve. National Geography article. Last access 20 May 2020. https://www.nationalgeographic.org/article/case-studygalapagos-marine-reserve/.

Castro-Rodas, D. (2016). Climatología costera y su influencia en las descargas residuales en la Península de Santa Elena (Tesis de pregrado). ESPOL, Guayaquil-Ecuador. 39 pp.

DOI: $10.13140 / R G .2 .2 .20697 .21603$

Editor-a. 2020. On being human in the face of a pandemic. Nat Cancer 1, 371 (2020).

https://doi.org/10.1038/s43018-020-0062-2.

Editor-b 2020. Science in the time of corona. Nat Ecol Evol 4, 665. https://doi.org/10.1038/s41559-020$\underline{1205-7}$

De Vito A., J. P. Gómez. 2020. Estimating the COVID-19 cash crunch: Global evidence and policy. Journal of Accounting and Public Policy. March-April 2020. https://doi.org/10.1016/j.jaccpubpol.2020.106741.

Eljarrat E. 2020. El resurgir del plástico por culpa del coronavirus. The Conversation. National Geographic article. Last access 22 may 2020.

https://www.nationalgeographic.com.es/naturaleza/resurgir-plastico-por-culpa-coronavirus 15488. 14 de mayo de 2020, 14:55.

GAD-Salinas, 2020. Demografía. Latest access 24 may 2020.

https://www.salinas.gob.ec/index.php/salinas/demografia/106-salinas.

Grube A. M., J. R. Stewart, V. Ochoa-Herrera. 2020. The challenge of achieving safely managed drinking water supply on San Cristobal island, Galápagos. International Journal of Hygiene and Environmental Health. 228. https://doi.org/10.1016/j.ijheh.2020.113547.

Covid-19 impacts on beaches and coastal water pollution: Management proposals post pandemic. Ormaza-González, Franklin I., Divar Castro-Rodas 
Hazel J., I.R Lawler, H. Marsh, S Robson. 2007. Vessel speed increases collision risk for the green turtle Chelonia mydas. Endang Species Res 3: 105-113.

Hyde, K. 2020. Residential Water Quality and the Spread of COVID-19 in the United States (April 9, 2020). Available at SSRN: https://ssrn.com/abstract=3572341 or http://dx.doi.org/10.2139/ssrn.3572341

INEC. 2016. Documento Técnico “Estadística Ambiental Económica en Gobiernos Autónomos Descentralizados Municipales" Gestión de Agua Potable y Alcantarillado 2016.

https://www.ecuadorencifras.gob.ec/institucional/home/.

John Hopkins university Corona Resource Center (24/may/2020). Latest access 24 may 2020. (https://coronavirus.jhu.edu/map.html)

Ketten, D.R. (2008) Underwater ears and the physiology of impacts: Comparative liability for hearing loss in sea turtles, birds, and mammals. Bioacoustics, vol. 17, no. 1-3, pp. 312-315.

Knauss J.A. 1963. Measurements of the Cromwell current. Deep Sea Research, 6, 1959-1960, Pages 265274, IN25-IN26, 275-286. https://doi.org/10.1016/0146-6313(59)90086-3.

Labott, S. M., Johnson, T. P., Fendrich, M., \& Feeny, N. C. 2013. Emotional risks to respondents in survey research. Journal of empirical research on human research ethics : JERHRE, 8(4), 53-66.

https://doi.org/10.1525/jer.2013.8.4.53.

Le Quéré, C., Jackson, R.B., Jones, M.W. et al. Temporary reduction in daily global $\mathrm{CO}_{2}$ emissions during the COVID-19 forced confinement. Nat. Clim. Chang. (2020). https://doi.org/10.1038/s41558-020-0797$\underline{x}$

Lucrezi S., M. Saayman, P. Van der Merwe. 2016. An assessment tool for sandy beaches: A case study for integrating beach description, human dimension, and economic factors to identify priority management issues. Ocean \& Coastal Management. 121, 1-22. https://doi.org/10.1016/i.ocecoaman.2015.12.003.

Mestanza C., C. M. Boteroc, G. Anfusoa, J. A. Chica-Ruiza, E. Pranzinid, A. Moosera. 2019a. Beach litter in Ecuador and the Galapagos islands: A baseline to enhance environmental conservation and sustainable beach tourism. Marine Pollution Bulletin. 140, 573-578

https://doi.org/10.1016/j.marpolbul.2019.02.003.

Mestanza-Ramón C. M., Sanchez-Capa, H. Figueroa-Saavedra, J. Rojas-Paredes. 2019b. Integrated Coastal Zone Management in Continental Ecuador and Galapagos Islands: Challenges and Opportunities in a Changing Tourism and Economic Context. Sustainability, 11, 6386; doi:10.3390/su11226386.

Moein S., M. Lenhardt, D. Barnard, J. Keinath, J. Musick. 1993. Marine turtle auditory behavior Citation: The Journal of the Acoustical Society of America 93, 2378. doi: 10.1121/1.406096.

Montecino V. C. B. Lange. 2009. The Humboldt Current System: Ecosystem components and processes, fisheries, and sediment studies. Progress in Oceanography, 83, 65-79.

https://doi.org/10.1016/j.pocean.2009.07.041.

Covid-19 impacts on beaches and coastal water pollution: Management proposals post pandemic. Ormaza-González, Franklin I., Divar Castro-Rodas 
Navarro, N. 2019.Community Perceptions of Tourism Impacts on Coastal Protected Areas. J. Mar. Sci. Eng. 7, 274.

NRDC. 2014. The Impacts of Beach Pollution. Natural Resources Defense Council. Accessed 16 may 2020. https://www.nrdc.org/sites/default/files/ttw2014 Impacts of Beach Pollution.pdf.

Pak H. and Zaneveld J. G. R. 1973. The Cromwell Current on the East Side of the Galapagos Islands Journal of Geophysical Research, 78, 7845-7859

Partelow S., H. Wehrden' O. Horn. 2015. Pollution exposure on marine protected areas: A global assessment. Marine Pollution Bulletin, 15 November, 352-358.

https://doi.org/10.1016/j.marpolbul.2015.08.026.

Pearson R.M., M. Sievers, E. C. McClure, M. P. Turschwell, R.M. Connolly. 2020. COVID-19 recovery can benefit biodiversity. Science 368, Issue 6493, pp. 838-839. DOI: 10.1126/science.abc1430.

Pecot, M.; Ricaurte-Quijano, C. 2019. Todos a Galápagos?' Overtourism in wilderness areas of the Global South. In, Overtourism: excesses, discontents and measures in travel and tourism. Editors: Milano, C.; Cheer, J. M.; Novelli, M. ISBN: 9781786399823. 2019 pp.70-85. DOI: 10.1079/9781786399823.0070.

PNG (2020). Informe Anual de Visitantes a las áreas protegidas de Galápagos 2019. Dirección del Parque Nacional Galápagos. Galápagos - Ecuador. http://www.galapagos.gob.ec/wpcontent/uploads/2020/01/INFORME-ANUAL-DE-VISITANTES-2019.pdf.

Randazzo W., P. Truchado, E. Cuevas-Ferrando, P. Simon, A. Allende, G. Sanchez. 2020. SARS-CoV-2 RNA titers in wastewater anticipated COVID-19 occurrence in a low prevalence are. medRxiv 2020.04.22.20075200; doi: https://doi.org/10.1101/2020.04.22.20075200.

Ricaurte-Quijano, Carla; Nacipucha, David; Gavilanes, Julio; Manner, Fanny; Calles, Alba; Cervantes, Eduardo. 2019. Beach Uses and Users in Four Beaches of the Ecuadorian Coast: The Importance of Physical and Socioeconomic Conditions for Recreational Beach Use Assessment in Latin American Contexts. Tourism in Marine Environments, Volume 14, Number 3, 2019, pp. 163-177.

DOI: https://doi.org/10.3727/154427319X15634413181250

Rosenbloom D., M. Jochen.2020. A COVID-19 recovery for climate DOI: 10.1126/science.abc4887

Samuel Y., S. J. Morreale, C. W. Clark, C. H. Greene M. E. Richmond. 2005. Underwater, low-frequency noise in a coastal sea turtle habitat. J. Acoust. Soc. Am. 117 (3)

Santander Rodriguez, V. P.2017. Plastic debris effect by zooplanktonic community in the Galapagos Islands-Santa Cruz and San Cristobal cases (Bachelor's thesis, Espol). 13 pp.

Statista, 2020. Economic impact of coronavirus (COVID-19) on the tourism sector in Ecuador in 2020, by scenario. Latest access 24 may 2020. https://www.statista.com/statistics/1106008/coronaviruseconomic-impact-tourism-scenario-ecuador/.

Stocker M. 2002. Ocean bio-acoustics and Noise Pollution: Fish, Mollusks and other Sea Animals' Use of Sound, and the Impact of Anthropogenic Noise in the Marine Acoustic Environment. Latest access 25

Covid-19 impacts on beaches and coastal water pollution: Management proposals post pandemic. Ormaza-González, Franklin I., Divar Castro-Rodas 
may 2020. https://ocr.org/ocr/wp-content/uploads/Ocean bioacoustics and Noise Pollution OCR.pdf,

Stumpf C. H., Raul A. Gonzalez, and Rachel T. Noble. 2013. Investigating the Coastal Water Quality of the Galapagos Islands, Ecuador. In, Science and Conservation in the Galapagos Islands: 173 Frameworks \& Perspectives, Social and Ecological Interactions in the Galapagos Islands. S.J. Walsh and C.F. Mena (eds.), 1, DOI 10.1007/978-1-4614-5794-7_10.

UNWTO. 2020. International Tourism and covid-19. Latest access 24 may 2020.

(https://www.unwto.org/international-tourism-and-covid-19)

Walsh S. and C.F. Mena. 2013. Science and Conservation in the Galapagos Islands: Frameworks \& Perspectives. ISBN 978-1-4614-5793-0. DOI 10.1007/978-1-4614-5794-7

Yunus A.P., Y. Masago, Y. Hijioka. 2020. COVID-19 and surface water quality: Improved lake water quality during the lockdown. Science of The Total Environment. 731, 20 August 2020, 139012. https://doi.org/10.1016/i.scitotenv.2020.139012

Zambrano-Alvarado J. 2020. Ballenas y delfines vuelven a la costa de Ecuador. www.eltelegrafo.com.ec. https://www.eltelegrafo.com.ec/noticias/sociedad/6/ballenas-delfines-costa-ecuador

Zambrano-Monserrate M. A. M. A. Ruano' L. Sanchez-Alcalde. 2020. Indirect effects of COVID-19 on the environment. Science of the Total Environment, 728, 138813.

ttps://doi.org/10.1016/i.scitotenv.2020.138813.

Covid-19 impacts on beaches and coastal water pollution: Management proposals post pandemic. Ormaza-González, Franklin I., Divar Castro-Rodas 